\section{Semantic Groups Of The Lexicon Of The Work Hibatul Hakoyik}

\author{
Sindorov Lutfulla Kurolovich \\ PhD Student, Jizzakh State Pedagogical Institute, \\ Uzbekistan
}

\author{
G open ACCESS \\ The American Journal of \\ Social Science And \\ Education Innovations \\ JULY 2020 \\ Page No.: 315-321 \\ Volume-II Issue-VII \\ PUBLISHED: 30 JULY 2020 \\ www.usajournalshub.com/inde \\ x.php/tajssei \\ Copyright: Original content \\ from this work may be used \\ under the terms of the \\ Creative Commons Attribution \\ 4.0 licence.
}

\title{
Abstract
}

Dividing words into thematic groups is a convenient way to systematically study the content of a language dictionary. The article analyzes the field of lexical units used in the work "Hibatul Hakoyik", their origin, the relationship of words related to their layer with the assimilation, and the scope of their use.

Keywords: Ahmad Yugnaki, "Hibatul Hakoyik", Yusuf Khos Hajib, "Qutadgu Bilig", "Devonu Lugotit Turk", sema, lexicon, lexeme, lexical unit, thematic group, anthroponym, toponym, zoonim, theonym, ancient Turkish language.

\section{Introduction}

The vocabulary of a language is constantly changing as it is directly related to the various activities of people, enriched by the development of society, science and technology. Because if the language is not enriched with new words, it will not be able to reflect the changes and innovations in the society. Therefore, the lexical structure of each language is such a treasure that it contains valuable information about the history of this people. The origin, life and culture of the people, their material and spiritual wealth, their role in the development of universal culture are reflected in the lexicon $[1,1978]$.

Thanks to language, the knowledge generated in each member of society becomes 
popular and can be developed by many. In addition, knowledge through language is passed from ancestor to generation orally and in writing, with the result that the new generation continues the work of the previous ancestor. This will ensure further development $[2,2010]$. From this point of view, it can be said that the lexical structure of the Uzbek language has gone through specific historical stages. Each word used in the current language has a specific date of occurrence depending on its ability to perform different tasks, change differently, and receive news. Some of these words were the basis for the creation of new words in accordance with the requirements of life in ancient times. A certain part, however, appeared much later and took a permanent place in the language $[3,1959]$. This, in turn, indicates the need to study vocabulary from a historical perspective. Indeed, a thorough study of the history of language is of great importance in correctly determining the current state of each literary language and in determining the ways of its development.

\section{The Main Findings And Results}

The study of the language of written sources helps to substantiate the theoretical principles of lexicology, which is one of the important tools in defining and evaluating the interactions, relations of the people speaking this language with other peoples. As the lexicon incorporates various internal and external influences in relation to other areas of language, it helps to identify changes and growth in the cultural, political, socio-economic life of the people [4, 1983]. In this sense, one of the most common ways to study the historical development of a language and the richness of its vocabulary is to analyze the words in the language by distinguishing thematic groups. Determining to which field the words used in the sources belong belongs to valuable information not only for linguistics but also for other disciplines. Also, the thematic grouping of lexemes in the language of written memoirs allows to get a full picture of the spirituality, legal level of the peoples of the period in which the work was created, the relations of cooperation with neighboring and fraternal peoples $[5,1996]$.

The grouping of words into thematic groups is done not through the internal laws of language, but rather through external signs. In this case, the leading factor is the category to which the meaning of the word belongs. In this respect, the division of words into thematic groups differs from the method of studying lexemes into lexical-semantic groups, and it does not embody the specific relations of language $[6,1970]$.

The division of words into thematic groups plays an important role in determining which areas of vocabulary in a particular vernacular language are rich or poor. Dividing one's own and assimilated layer lexicon into thematic groups and comparative study of them allows us to determine in which areas words are preserved in their own layer, in which areas lexemes have historically become obsolete and have been replaced by assimilated words. At the same time, it should be noted that information about the sociopolitical life, cultural life, and religious views of the people finds its clearest expression in the thematic groups of the word. Hence, the study of lexemes into thematic groups serves to shed light on aspects of language related to folk life [7, 1985]. 
Based on the existing experience in the analysis of the lexicon of Turkic languages in thematic groups in Turkology and Uzbek linguistics, we tried to study the lexicon of the work "Hibatul Hakoyik" by thematic groups. Our observations show that lexemes belonging to the following 19 thematic groups were recorded in the epic language:

I. Anthroponyms: Umar [8, 1972], Usmān, Ali, Amir Muhammad Dādsipāhsālarbek, Anuširvān, Xoja Arnāb Arslanxoja Tarxan, Mahmud Yugnakiy, Adib Ahmad.

II. Toponyms: Kašğar, Yügnäk.

III. Zoonyms: arslan, yağan - "Fil - elephant", yïlan,älik - "kiyik - deer", fil elephant.

IV. Theonyms: yazuq, qul, savāb, insāf, halāl, harām, e'tiqād, rahmat.

V. Food and beverages: azuq, asal, aš - «ovqat - food», šarāb, suw.

VI. Names of man-made objects [9, 1981]: ton - rope - «ton, wearing», yol - road «road», közgü - «oyna - window», binā - «bino - building».

VII. Names of human body parts: baš - «bosh - head», köz - «ko'z - eyes», qarïn «qorin - stomach», elik - «ko'l - arm», qol - «qo'l - arm», azaq.

VIII. Words denoting kinship, closeness: ata - «ota - father», ana - «ona - mother», er - «erkak - man», tiši - «xotin - wife », oğul - «o'g'il - sun».

IX. Lexemes related to the concept of age: qarï - «keksa - old», qoča - «qari old», yigit - «yigit - boy».

$X$. Lexemes related to the concept of age: köni - «to'g'ri - right», yalğan «yolg'on - lie», ürün - «oq - white», arïğsïz - «iflos, nopok - dirty», qatï̌ - «qattiq hard», āsān - «qulay - comfortable», körklük - "go'zal - beautiful", yawuz «yomon - bad», ačïğ - «achchiq - chilly», süčük - «chuchuk - sweet», tat "maza, ta'm - tast", yid - «hiq - smell», kičik - «kichik - small», key - «keng broad».

XI. Lexemes denoting concepts related to movement, speech, and activity: tüš- «tushmoq - to go down», bul- - «qo'lga kiritmoq, erishmoq - to achieve», čal- «tashlamoq - to drop», tur-- «artmoq - to clean», az- - «adashmoq - to roam», art- - «artmoq - to wipe», sal- - «calmoq - amount», izlä- - «islamoq - to search», bezä- - «bezamoq - to decorate», sewin- - "sevinmoq - to enjoy", uwtan- «uyalmoq - to be shy», ayt- - «aytmoq - to say», sözlä- - «so'zlashmoq - to talk to», sor- - «so'ramoq - to ask for», yat- - «yotmoq - to lay down», qon- «qo'nmoq - to land», baq- - «qaramoq - to look».

XII. Lexical units representing concepts related to trade and monetary relations: arqiiš - «karvon - karavan», asïğ - «foyda - profit», učuz - «arzon cheap», amānat - «omonat - deposit», tawar - «Tovar - goods», māl - «mol, Tovar -goods», dinar - «dinor - dinor »( currency).

XIII. Lexical units representing socio-political concepts: el - «el - people», bozun «xalq - people, folk», hukm - «hokum - order», baylïq - «boylik - wealth», māllïq «mollik, mulkdor - owner ». čĭgaylïq - «kambag'allik - poverty », mālsïz - «molsin, 
kambag'la - poverty », hadiya - «hadya- cherity», qaravaš - cho'ri, xuzmatkor servant.

$X I V$. Words denoting numbers, quantities and scales: tümän - «o'n ming, ten thousand», ikinč - «ikkinchi - second», üčünč - «uchunchi - third», hazār - «ming thousand», qol - «dona», on tort, tort, tortčïlanč - «to'rtinchi - fourth», qarï o'zchov birligi - unit of measure, bir - one, iki two, on.

$X V$. Words used against people: ādam - «isnon - human», kiši - «odam - person», kim - «kim - who», dost - «do'st - freind», yārān - «do'st - friend», dušman g'anim - enemy».

XVI. Abstract concepts: yazuq - «gunoh - sin», unar - «hunar - craft », tüš - «tush dream», baxt - «baxt - happiness», inč - «tinch - peice».

XVII. Military vocabulary: bek - «bek - suffix for the name of the people who are from royal society», yağï - «dushman - enemy», dušman - «g'anim - enemy», oq - «o'q - bullet».

XVIII. Lexemes denoting the concept of geographical object: on - «o'ng - right», tüz - «tekislik - plane », köl - «qo'l - arm».

XIX. Words expressing the concepts of time: kün - «kun - day», kündüz - «Kunduz - day time», ozağ - «qadim, o'tmish - ancient, past », tün - «tun - night» and so on.

At the same time, when comparing the lexemes of the mentioned thematic groups with the vocabulary of the first sources of the ancient Turkic language and the old Turkic literary language, their historical roots, semantic development and origin become clear. For example, in Yusuf Khas Hajib's Qutadgu Bilig, the word aš means "food, meal" and "feast": Ularda birisi kodängä aš-ul, ya sunnat ašï ya tuğursa oğul- One of them is the feast of marriage (marriage), or the feast of circumcision, or the feast of childbirth (ATD, 61).

This verse clearly expresses the rituals that the ancestors used to set the table and make soup. When the time comes, it should be noted that in the epic, the donation dedicated to the death of a person is expressed by the addition of yoğ ašï. In Devonu Lugotit Turk we read: аш - meal, food. It is also called ash in the throat. Айақ а:шла - Put the drip into the container (MKT, I, 72). In the epic Hibatul Hakoyik, it comes in the context of "meal, food": Ayursan kezim, ton, šarāb, aš keräk. It turns out that the meaning of the term "soup, pilaf" was formed later, that is, as a result of narrowing of meaning.

In the epic, the Turkish term arslan occurs: Va lekin bušardašar\raarslanï. We first come across this zoon in the first sources of the Old Turkic language: alïn arslan tutar küčin sïčğan tutmas - if it is possible to catch a lion by cunning, it is impossible to catch a mouse by force (MK, III, 419). Aslan (11-12) and arsalan (11) and arslan (103) were used in Tarjumon and Kitab ul-Idrok. Arslan (MN, 293b7), arsalan (G, 128a3) in Khorezm monuments of the XIV century. Occurs in the works of Alisher Navoi and in the modern Uzbek literary language (OTIL, I, 65) in the form of arslan: Bahrām arslanlarnï halāk qïlïb, tājni bašïğa qoyïb taxtga oturdï (Navoi,I,116). V.Radlov's dictionary contains information about the use of phonetic forms arsillan in Teleut, Altaic, Kyrgyz, arslan in Tatar, Tobol (Experience of the Dictionary of Turkic Dialects, I, 327-328), Ottoman 
Turkish, Azerbaijani, Crimean languages aslan (Experience of the Dictionary of Turkic Dialects, I, 546). In general, the arslan zoononym meant both male and female lion. As an astroponym, this zoonim also served to express the name "zodiac" in Yusuf Khos Hajib's "Qutadg'u Bilig". The term is formed by means of -lan affixes in ars words representing the lion's "roar" and "growl" (Etymological Dictionary of Turkic Languages, I, 84). G. Vamberi connects the etymology arslan with the words aris "strong" + lan "wild" (Etymological Dictionary of Turkic Languages, I, 178). According to A. Shcherbak, arsïlanar "light brown" and "brown" are composed of an words "beast", - sïl intensive forms (Historical development of the vocabulary of the Turkic languages, 197). In our opinion, E. Sevortyan's opinion is more correct. Because the scientist approached the etymology of the term taking into account the sound made by the animal.

The term Yïlan ( $M K, I, 232$ ) was first mentioned in the Orkhon-Enasay monuments: altun bašliğ yïlan män (ATD, 266). Zoonism is also expressed in the language of the study: Yïlan yumšaq erkän yavuz fe'l tutar. In the monuments "Al-Tukhfa" (10a12) and "Kitob Bulgat" the form ïlan (15a5) is visible. The term is also used in ancient Uzbek language monuments: fusungar afsun bilä yïlannï töšükdin čïqarur (Navoi, III, 217). Radlov's dictionary states that ïlan (Experience of the Dictionary of Turkic Dialects, I, 1445) phonetic forms were used in the Taranchin and Chigatay languages, and yïlan (Experience of the Dictionary of Turkic Dialects, III, 518) in the Tatar, Quman, Altai, Teleut, Lebedin, and Chulm languages. The term is derived from the ancient Uyghur inscriptions and the "Devon" as an astronomical term meaning the sixth of the twelve muchal years in Turkish, the year of the serpent. Zoonim yill = is formed by adding the affix - an to the verb "to smile" (Experience of the Dictionary of Turkic Dialects, III, 482). Synonyms su'ban in Arabic and mor in Persian-Tajik in the works of Alisher Navoi (Navoi, III, 217) were also used in the 14th century Khorezm monuments: Berür qoy kütmägä Musağa su'ban (BC, 292a5).

The Turkish term älik is given in the Tajumon in the form ilik (11-6). Figure Älik Enasay monuments and Yusuf Khos Hajib's work "Kutadgu Bilig" means "female deer", "wild goat": Ič yer äliki artsun - let female deer multiply on the surface (ATD, 171). In the epic "Hibatul Hakoyik" he continued: Qazā birlä ilnür tuzaqqa älik. Phonetic forms such as elik (Experience of the Dictionary of Turkic Dialects, I, 815) in Kyrgyz, Sugai, Black Kyrgyz, ilik (Experience of the Dictionary of Turkic Dialects, I, 1384) in Barbin, älik (Experience of the Dictionary of Turkic Dialects, I, 815) in Altaic, Teleut, Sayan, Chulm, and Saline languages were used. It can be found in V.Radlov's dictionary. Although the term is not found in other sources, it is still preserved in its original meaning in Turkish today (Experience of the Dictionary of Turkic Dialects, 269). According to F. Lessing, elik etymologically Mongolian ili/il is related to the word "young deer", "deer child" (Etymological Dictionary of Turkic Languages, I, 265).

The Turfan texts of the verb čal, the monument "Golden Light" contain the meanings of the verb čal "o'rmoq - to strike", "tashlamoq - to throw" (in the figurative 
sense) can be found in the "Ancient Turkic Dictionary": ...birgäü yerkä čalïp -thrown to the ground together (ATD, 137). 11th century monuments, in Qutadg'u Bilig, "beat":... ölürdä ulïp yerkä čalmïš bašï - after death, the head throws itself to the ground- čaqsa tutnur čal bilnür- "to throw", says - known, known (ATD, 137) semaphores are observed. In the epic "Hibatul Hakoyik", the semaphore of "throwing" is mentioned: Xasislarnï kötrüb nafsnï čalïb.

The work "Hibatul Hakoyik" lexically, phonetically and grammatically, first of all, reflects all the features of the Turkic literary language used in the XI-XIII centuries, shows that the Turkic tribal languages are much more developed. At the same time, this work has much in common with the language of works created in the XIII-XIV centuries, despite certain differences and differences in terms of its linguistic features. At the same time, it is clear that this work is a great step in the transition from the Old Turkic literary language to the old Uzbek language, and is approaching it. This confirms the close relationship between the languages of the Turkic tribes at that time, as a result of their development, the formation of the Uzbek language was accelerated, as well as the process of formation of other Turkic languages continued. This means that "Hibatul Hakoyik" was popular not only in East Turkestan, but also in Movaraunnahr, Khorasan and other regions. As it was linguistically understandable to all Turkic peoples, it retained its influence during the Navoi period.

Indeed, the study of language vocabulary in the diachronic aspect is of particular importance not only for determining the ways in which language facts develop, but also for studying the history of the people who created it. Hence, the history of each language is related to the past of the people belonging to that language. Whatever happens in the history of a nation has more or less the same effect on language. This occurs primarily in the vocabulary richness of the language. In this regard, it can be said that the analysis of the lexicon of "Hibatul Hakoyik" by thematic groups showed that the language of the monument used words belonging to different thematic groups, which reflected the lifestyle, socio-economic, cultural and spiritual development of the people at that time. At the same time, lexemes from other languages also played an important role in the formation of these thematic groups.

\section{Conclusion}

Language of the novel is mainly divided into thematic groups such as "Lexemes denoting concepts related to movement, speech and activity", "Lexemes denoting features and symbols", "Theonyms", "Names of man-made objects", "Words expressing socio-political concepts"; unwanted terms are actively used.

In the game there are three lexemes that represent almost all spheres of life-the subject, the events. Consequently, the division of words into thematic groups is considered a convenient method of systematic study of the composition of the language dictionary, it helps to determine the area in which lexical units used in the narrative belong, the origin, the interaction of related words with their syllables, as well as the scope of their application, to assess the historical and modern state of the novel. 


\section{References}

[1]. Mahmudov K. (1972) About Ahmad Yugnaki's work "Hibatul-Hakoyik": introduction, phonetics, morphology, text, transcription, commentary, dictionary. -T .: Fan. - p. 298.

[2]. Tursunova T. (1978) Vocabulary of applied art in Uzbek language. -Tashkent. Fan. p. 140.

[3]. Musaev K. (1975) Vocabulary of Turkic languages in comparative coverage (Western Kypchak group). - Moscow. - p. 359.

[4]. Rustamov A. (2010) Word for word. - Tashkent. EXTREMUM PRESS. - p. 135.

[5]. Mutallibov S. (1959) A brief essay on the history of morphology and lexicon. Tashkent. Fan. - p. 239.

[6]. Bafoev B. (1983) Vocabulary of Navoi's works. - Tashkent. Fan. - p. 157.

[7]. Abdulxayrov M. (1996) Lexical layers of the "Devoni Munis" language. Candidate of Philological Sciences. Diss. - Tashkent. - p. 122.

[8]. Goldin V.E. (1970) On one aspect of studying thematic groups of words. In Sat: Language and Society. Issue 2. - Moscow. - pp. 56-62.

[9]. Filin F. (1957) On lexico-semantic groups of words. // Esikovedenski research in honor of the academic. ST. Mladenova. - Sofia. - pp. 525-531.

[1]. Begmatov E. (1985) Lexical layers of modern Uzbek literary language. - Tashkent. Fan. - p. 200.

[11]. Asomiddinova M. (1981) Clothing names. - Tashkent. FAN. - p. 98.

[12]. Gafurova L. (1991) Household vocabulary of the modern Uzbek language. Tashkent. FAN. - p. 216.

[13]. Usmonova Sh. (2011) A study of common household vocabulary in Altaic languages. Philological Sciences. Ph.D. Diss. avtoref. - Tashkent. - p. 42. 